\title{
THE EFFECT OF TECHNOLOGICAL AND BEHAVIORAL ON THE ADOPTION OF THE SHOPEEPAY MOBILE PAYMENT
}

\author{
Renofia Desia Halim \\ Management Department, University of Surabaya, Indonesia \\ renofiadesia@gmail.com \\ Fitri Novika Widjaja * \\ Management Department, University of Surabaya, Indonesia \\ fitri@staff.ubaya.ac.id. \\ Antonius Budhiman S. \\ Management Department, University of Surabaya, Indonesia \\ budhiman@staff.ubaya.ac.id.
}

*Corresponding author

\begin{abstract}
This study aims to examine the effect of technological and behavioral attributes on the adoption attributes of the ShopeePay mobile payment application in Indonesia. The application is known as financial technology (fintech), which combines information technology and financial systems. The approach used in this research is a quantitative approach that was processed using SPSS and AMOS. Data collection in this research was done by distributing online questionnaires using a google form to ShopeePay users who used the application in the past month. The results of this study indicate that behavioral intention and social influence variables have an effect on actual use, perceived usefulness and perceived ease of use have an effect on behavioral intention, perceived ease of use and responsiveness have a positive effect on perceived usefulness, and responsiveness and security variables have a positive effect on perceived ease of use, also has a positive effect on social influence.

Keywords: Technological Attributes, Behavioral Attributes, Adoption Attributes, Mobile Payment.
\end{abstract}

\section{INTRODUCTION}

These days, technological advancement eases people to live their daily lives. The advancement is used by society for a faster and more practical lifestyle, and technology can support work effectively and efficiently. This is different for people who consider technology as something new and not easy to understand. Society is required to adapt to technological advancement so that technology can make life more modern. Technology is created to be practically applied, used repeatedly, provide shared values and benefits that anyone can enjoy (Castells, 2004).

The latest technological innovation currently growing is a financial technology (fintech) that combines technology and the financial system (Annas \& 
Anshori, 2021; Hsueh \& Kuo, 2017). Technology makes today's transactions very easy and can be done online, starting from payments, fund transfers to fundraising. Fintech refers to the provision of financial services through technology on smartphones (Gai, Qiu, \& Sun, 2018; Suryono, 2019). Smartphones are also experiencing technological advancement to improve financial inclusion globally, change lifestyles, and become a financial solution for the people of Indonesia.

The emergence of smartphones and fintech innovations in people's lives has caused the use of mobile payments to grow rapidly (Teo, Tan, Ooi, \& Lin, 2015) and become the primary driver of financial inclusion. We now encounter a lot of acceptance and use of mobile payments compared to the cash system (Grohmann, 2018; Sastiono \& Nuryakin, 2019). Today's society does not need to be afraid to carry large amounts of cash that could be at risk of being lost or difficult in counting the cash as by using mobile payments, the society needs to scan a barcode to complete a transaction swiftly. Singh, Sahni, \& Kovid (2020) that conducted a study entitled "What Drives FinTech Adoption? A Multi-Method Evaluation using an Adapted Technology Acceptance Model", investigated the concept of actual use of fintech that is influenced by behavioral intention. An online survey was conducted on a total of 439 internet users in Mumbai and Delhi. This study also examined the determinants of behavioral intention, which include behavioral attributes (perceived usefulness, social influence, and perceived ease of use) and technological attributes (responsiveness and security) to see other factors that can affect the actual use of fintech. The results of this study indicated that behavioral intention has no effect on actual use, and social influence does not affect usefulness. Albayati, Kim, \& Rho (2020) conducted a study through an online survey on a total of 251 mobile payment users in Korea. The results of this study showed that social influence has a positive effect on perceived usefulness. Research conducted by (Senyo \& Osabutey, 2020) was done through an online survey to a total of 294 mobile payment users in Ghana. The results of this study indicated that behavioral intention has a positive effect on actual use. Singh et al. (2020) said that technological attributes include responsiveness and security, while behavioral attributes include perceived usefulness, social influence, and perceived ease of use, and adoption attributes include behavioral intention and actual use variables. According to Singh et al. (2020), responsiveness refers to the user perception of the effectiveness and excellence of services which refers to the accuracy of the services delivered along with clear, current, and complete information available on the mobile payment services. Singh et al. (2020) stated that security is the security of mobile payments which is the main factor triggering confidence while doing financial transactions. Social influence defined as the extent of the influence of others to use technology (Venkatesh, Thong, \& Xu, 2012). Singh et al. (2020) defined perceived usefulness as a person's belief that technology will improve its performance. Singh et al. (2020) defined perceived ease of use as the degree to which one believes that using the technology is free of effort. Purwianti \& Tio (2017) explained that behavioral intention determines the possibility that users will take specific actions in the future. Isaac, Aldholay, Abdullah, \& Ramayah (2019) said that actual use could be described as the extent 
to which individuals can use information system functions, based on the nature, frequency, and period of use of specific technologies. Since 2009, Bank Indonesia has been supporting the use of mobile payments in Indonesia. Zhou (2013) saw a vast potential in mobile payment services that allows companies in Indonesia to engage in mobile payments such as GoJek with GoPay, Lippo with OVO, Shopee with ShopeePay, and several state-owned companies such as LinkAja, and EMTEK with DANA to grow. These mobile payment companies are competing to win the hearts of the Indonesian people by offering attractive promos and providing convenience through their mobile payment application service to become a means of daily payment.

This study used the object of PT AirPay International Indonesia, namely ShopeePay, which is an electronic money service that can be used as a payment method for the largest e-commerce application in Indonesia, namely Shopee, which was launched for the first time in Singapore in 2015. ShopeePay obtained an e-money license from Bank Indonesia in August 2018 and was officially released in November 2018. However, in 2019, ShopeePay began to spread its wings to transact thousands of merchant types such as food and beverages, retail, and other services. After its launch, ShopeePay has become the most popular mobile payment in Indonesia in almost two years. The presence of ShopeePay as a payment feature increases transactions at Shopee itself. In Q3 of 2020, Iprice stated that Shopee got the most visitors compared to other online marketplaces with 96.532 million visitors per month and 93.44 million visitors per month in the previous quarter. This data proves that many people visit this e-commerce. Shopee provides attractive offers by utilizing payments using ShopeePay. Through ShopeePay, people can recognize cashless payments, making it easier and faster for users in transactions, both bill payments in Shopee and merchants who have collaborated with ShopeePay. (Source: iprice.co.id).

This study aims to prove the effect of behavioral intention determinants that include behavioral attributes (perceived usefulness, social influence, and perceived ease of use) and technological attributes (responsiveness and security) to see other factors that can affect the actual use of ShopeePay fintech.

\section{RESEARCH METHODS}

This research is conclusive descriptive. This study used primary data. Questionnaires were distributed using online media of Google forms. The target respondents required to complete this questionnaire were respondents who used ShopeePay mobile payment in the past month. This study used a Likert Scale, which provides an assessment of several statements based on the adjectives to be measured starting from 1 (one) representing "Strongly Disagree" to 5 (five) indicating "Strongly Agree". The target population in this study was ShopeePay users who are over 20 years old.

The sampling technique used in this research was non-probability sampling, with a purposive sampling method. Non-probability sampling is a technique that does not provide equal opportunities for each population to be selected as research subjects. It is known that the population in this study is unlimited, so the minimum number of samples, according to Hair (2009), must be 130 respondents. 
The data processing method was carried out by testing the validity and reliability of the variable measurement instrument. The validity testing results are declared valid if the value of $r$ count $>r$ table or shows a significance level of $p<$ 0.05 and the Pearson correlation value $>0.3$. Meanwhile, the variable is declared reliable if the Cronbach's Alpha value > 0.6, which will provide a descriptive statistical picture of the mean and standard deviation of each variable measurement instrument. The next step was to test the sixteen existing hypotheses using the Structural Equation Modeling (SEM) method of the Statistical Analysis of Moment Structures.

\section{RESULTS \& DISCUSSION}

The data collected through questionnaires to 214 respondents were then processed for validity and reliability testing. After the data showed that the measurement instrument was valid and reliable, then data processing was carried out. Table 1 exhibits the profile of respondents in this study, most of the respondents were females, $84 \%$, and $66 \%$ of them were in the age group of 20-24 years. Descriptive data that measures the responses of respondents related to the statement of each variable. The following table shows the mean and standard deviation of each variable.

Table 1.

The mean and standard deviation of each variable

\begin{tabular}{|c|c|c|c|}
\hline No & Statements & Mean & Std. Dev. \\
\hline \multirow[t]{3}{*}{1} & Responsiveness & 4.221 & 0.912 \\
\hline & $\begin{array}{l}\text { ShopeePay gives information about time taken to } \\
\text { complete financial transaction }\end{array}$ & 4.19 & 0.951 \\
\hline & ShopeePay gives prompt service as promised & 4.26 & 0.874 \\
\hline \multirow[t]{6}{*}{2} & Security & 4.210 & 0.809 \\
\hline & ShopeePay has good reputation for its security & 4.19 & 0.779 \\
\hline & Safe to complete financial transaction & 4.37 & 0.725 \\
\hline & $\begin{array}{l}\text { ShopeePay gives the feeling of safety for personal } \\
\text { information }\end{array}$ & 4.14 & 0.855 \\
\hline & $\begin{array}{l}\text { ShopeePay gives trustworthy security service is } \\
\text { trustworthy }\end{array}$ & 4.19 & 0.829 \\
\hline & ShopeePay has adequate security features & 4.16 & 0.837 \\
\hline \multirow[t]{4}{*}{3} & Social Influence & 3.093 & 1.408 \\
\hline & I use ShopeePay as my family and friends are using it & 3.39 & 1.316 \\
\hline & I use ShopeePay as my colleagues are using it & 3.21 & 1.412 \\
\hline & I use ShopeePay as my spouse is using it & 2.68 & 1.405 \\
\hline \multirow[t]{4}{*}{4} & Perceived Usefulness & 4.529 & 0.759 \\
\hline & $\begin{array}{l}\text { Using ShopeePay eases me to transact according to the } \\
\text { nominal paid without any change }\end{array}$ & 4.56 & 0.740 \\
\hline & $\begin{array}{l}\text { Using ShopeePay eases me to make payments at } \\
\text { merchants }\end{array}$ & 4.49 & 0.786 \\
\hline & Using ShopeePay increases effectiveness in transactions & 4.54 & 0.754 \\
\hline \multirow[t]{2}{*}{5} & Perceived Ease of Use & 4.324 & 0.816 \\
\hline & ShopeePay is easy to learn & 4.51 & 0.717 \\
\hline
\end{tabular}




\begin{tabular}{lcc} 
& & (cont.) \\
\hline ShopeePay is easy to browse & 4.42 & 0.757 \\
ShopeePay is easy to use & 4.53 & 0.779 \\
ShopeePay gives a positive experience & 4.28 & 0.826 \\
ShopeePay provides clear and understandable & 4.28 & 0.773 \\
interactions & & \\
ShopeePay has an attractive design and appearance & 4.07 & 0.891 \\
ShopeePay eases users to fully use the application & 4.18 & 0.861 \\
6ehavioral intention (BI) & 4.464 & 0.777 \\
If I can access ShopeePay, I intend to use it & 4.46 & 0.754 \\
If I can access ShopeePay, I will use it & 4.53 & 0.716 \\
I plan to use ShopeePay in the near future & 4.41 & 0.855 \\
Actual Use & 3.886 & 0.916 \\
How likely are you to use ShopeePay? & 3.98 & 0.883 \\
I use ShopeePay regularly/periodically & 3.71 & 0.954 \\
I often use ShopeePay & 3.97 & 0.890 \\
\hline
\end{tabular}

Respondents' perceptions of the seven research variables show a positive value with the mean value of all variables are greater than 3 with the smallest standard deviation value of 0.759 on the perceived usefulness variable, and the largest is 1.408 on the Social Influence variable. The highest mean of respondents' perceptions is 4.529 on the Perceived Usefulness variable, while the lowest mean of respondents' perceptions is 3.093 on the Social Influence variable. This signifies that the average respondents feel that it is easy to transact using ShopeePay, while the choice to use ShopeePay is not due to the influence of spouses, friends, or family but due to their own choice.

The seven research variables were then processed to answer sixteen research hypotheses with a research model as shown in Figure 1, where Technological Attributes are hypothesized to affect behavioral and adoption attributes.

The testing stage of this measurement model used AMOS version 26 with the Confirmatory Factor Analysis (CFA) method to test all variables and their indicators. The index value in this measurement model is based on goodness-offit, which is divided into CMIN/DF, RMSEA, CFI, and TLI, which show good fit results, while GFI shows marginal fit results. After conducted a goodness-of-fit of the measurement model and the Confirmatory Factor Analysis (CFA) results meet the requirements, the next step was to test the Average Variance Extract (AVE) and Construct Reliability (CR). 


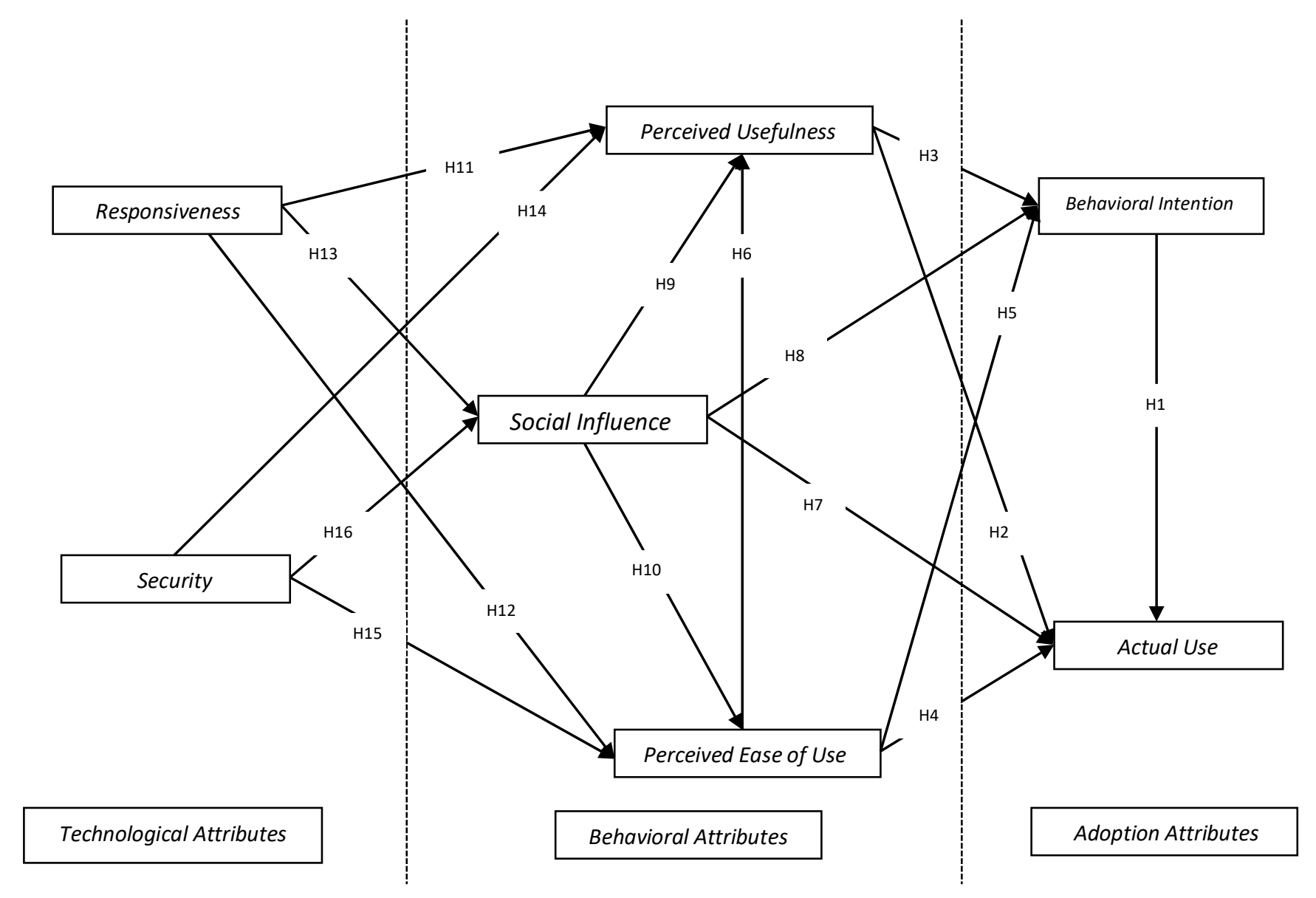

Figure 1.

\section{Research Model}

In Table 2, it can be seen that the Average Variance Extract is declared valid because all data shows a value of more than 0.5 for each variable. Construct reliability is declared reliable because all data shows a value of more than 0.7 on each variable. If the AVE and CR test conditions are met, then the next step is to test the structural model. The next step is to do the goodness-of-fit test of the structural model in this study. CMIN/DF is classified as good fit because it gets a value of 1.930, which is below 3.00. RMSEA is classified as good fit because it gets a value of 0.066 , which is below 0.08. GFI is classified as marginal fit because it gets a value of 0.836 , which is above 0.80 , and the CFI is classified as good fit and acceptable because it gets a value of 0.932 , which meets the requirements of 0.90 . TLI is classified as good fit because it gets a value of 0.921 , which is $\geq 0.90$. 
Table 2.

Average Variance Extract (AVE) and Construct Reliability (CR)

\begin{tabular}{|c|c|c|c|c|}
\hline Variable & Std. Loading $(\lambda)$ & AVE & CR & Remarks \\
\hline \multicolumn{5}{|c|}{ Responsiveness (RS) } \\
\hline RS1 & 0.694 & \multirow[t]{2}{*}{0.556} & \multirow[t]{2}{*}{0.714} & \multirow[t]{2}{*}{ Valid \& Reliable } \\
\hline $\mathrm{RS} 2$ & 0.795 & & & \\
\hline \multicolumn{5}{|l|}{ Security (SC) } \\
\hline $\mathrm{SC} 1$ & 0.781 & \multirow{5}{*}{0.709} & \multirow{5}{*}{0.923} & \multirow{5}{*}{ Valid \& Reliable } \\
\hline $\mathrm{SC} 2$ & 0.763 & & & \\
\hline $\mathrm{SC} 3$ & 0.899 & & & \\
\hline $\mathrm{SC} 4$ & 0.904 & & & \\
\hline SC5 & 0.854 & & & \\
\hline \multicolumn{5}{|c|}{ Social Influence (SI) } \\
\hline SI1 & 0.748 & \multirow{3}{*}{0,687} & \multirow{3}{*}{0.866} & \multirow{3}{*}{ Valid \& Reliable } \\
\hline SI2 & 0.965 & & & \\
\hline SI3 & 0.756 & & & \\
\hline \multicolumn{5}{|c|}{ Perceived Usefulness (PU) } \\
\hline PU1 & 0.744 & \multirow{3}{*}{0,673} & \multirow{3}{*}{0.860} & \multirow{3}{*}{ Valid \& Reliable } \\
\hline PU2 & 0.908 & & & \\
\hline PU3 & 0.802 & & & \\
\hline \multicolumn{5}{|c|}{ Perceived Ease of Use (PEOU) } \\
\hline PEOU1 & 0.802 & \multirow{7}{*}{0,638} & \multirow{7}{*}{0.925} & \multirow{7}{*}{ Valid \& Reliable } \\
\hline PEOU2 & 0.847 & & & \\
\hline PEOU3 & 0.792 & & & \\
\hline PEOU4 & 0.823 & & & \\
\hline PEOU5 & 0.858 & & & \\
\hline PEOU6 & 0.722 & & & \\
\hline PEOU7 & 0.741 & & & \\
\hline \multicolumn{5}{|c|}{ Behavioral intention (BI) } \\
\hline BI1 & 0.915 & \multirow{3}{*}{0,713} & \multirow{3}{*}{0.880} & \multirow{3}{*}{ Valid \& Reliable } \\
\hline BI2 & 0.910 & & & \\
\hline BI3 & 0.689 & & & \\
\hline \multicolumn{5}{|c|}{ Actual Use (AU) } \\
\hline AU1 & 0.872 & \multirow[t]{3}{*}{0,802} & \multirow[t]{3}{*}{0.924} & \multirow[t]{3}{*}{ Valid \& Reliable } \\
\hline AU2 & 0.918 & & & \\
\hline AU3 & 0.897 & & & \\
\hline
\end{tabular}

After completing all the tests by recapitulating data from all 214 samples and analyzing the measurement and structural models, the next step was hypothesis testing. AMOS version 26 software was used to test the hypotheses that have been put forward to show acceptance or rejection based on all the tests that have been carried out. 
Table 3.

Results of Goodness of Fit Test of Structural Model

\begin{tabular}{ccccc}
\hline No & Goodness of Fit & Criteria & Results & Remarks \\
\hline 1 & CMIN/DF & CMIN/DF $\leq 3$ & 1.930 & Good Fit \\
2 & RMSEA & RMSEA $\leq 0.08$ & 0.066 & Good Fit \\
3 & GFI & GFI $\geq 0.80$ & 0.836 & Marginal Fit \\
4 & CFI & CFI $\geq 0.90$ & 0.932 & Good Fit \\
5 & TLI & TLI $\geq 0.90$ & 0.921 & Good Fit \\
\hline
\end{tabular}

The benchmark that becomes the provision for testing this hypothesis uses the value of the Critical Ratio |C.R.| or by looking at the probability value. If the Critical Ratio value $>1.96$ or the probability value $<0.05$, then the hypothesis can be interpreted that the independent variable has a significant effect on the dependent variable. The following is a table of hypothesis testing results containing the standardized estimate, critical ratio, and p-value of each hypothesis that has been put forward in this study.

Table 4.

Hypothesis Testing

\begin{tabular}{|c|c|c|c|c|}
\hline Hypothesis & $\begin{array}{c}\text { Std. Estimate } \\
(\beta)\end{array}$ & $\begin{array}{c}\text { Critical } \\
\text { Ratio (CR) }\end{array}$ & $\mathrm{p}$ - values & Remarks \\
\hline $\mathrm{H} 1: \mathrm{BI} \rightarrow \mathrm{AU}$ & 0.094 & 2.718 & 0.007 & Supported \\
\hline $\mathrm{H} 2: \mathrm{PU} \rightarrow \mathrm{AU}$ & 0.118 & 0.016 & 0.987 & Not Supported \\
\hline $\mathrm{H} 3: \mathrm{PU} \rightarrow \mathrm{BI}$ & 0.102 & 2.514 & 0.012 & Supported \\
\hline H4: PEOU $\rightarrow$ AU & 0.118 & 1.430 & 0.153 & Not Supported \\
\hline H5: PEOU $\rightarrow$ BI & 0.097 & 4.834 & $* * *$ & Supported \\
\hline H6: PEOU $\rightarrow$ PU & 0.083 & 3.711 & $* * *$ & Supported \\
\hline $\mathrm{H} 7: \mathrm{SI} \rightarrow \mathrm{AU}$ & 0.056 & 3.322 & $* * *$ & Supported \\
\hline $\mathrm{H} 8: \mathrm{SI} \rightarrow \mathrm{BI}$ & 0.046 & 0.987 & 0.324 & Not Supported \\
\hline H9: SI $\rightarrow$ PU & 0.038 & -0.855 & 0.393 & Not Supported \\
\hline H10: SI $\rightarrow$ PEOU & 0.039 & 0.981 & 0.327 & Not Supported \\
\hline $\mathrm{H} 11: \mathrm{RS} \rightarrow \mathrm{PU}$ & 0.081 & 4.014 & $* * *$ & Supported \\
\hline $\mathrm{H} 12: \mathrm{RS} \rightarrow \mathrm{PEOU}$ & 0.074 & 3.426 & $* * *$ & Supported \\
\hline H13: RS $\rightarrow$ SI & 0.134 & -0.550 & 0.582 & Not Supported \\
\hline $\mathrm{H} 14: \mathrm{SC} \rightarrow \mathrm{PU}$ & 0.074 & -0.035 & 0.972 & Not Supported \\
\hline $\mathrm{H} 15: \mathrm{SC} \rightarrow \mathrm{PEOU}$ & 0.075 & 4.830 & $* * *$ & Supported \\
\hline $\mathrm{H} 16: \mathrm{SC} \rightarrow \mathrm{SI}$ & 0.134 & 3.437 & *** & Supported \\
\hline
\end{tabular}

Based on the results of hypothesis testing, it is known that there are nine (9) supported hypotheses and seven (7) not supported hypotheses. The supported hypotheses are $\mathrm{H} 1, \mathrm{H} 3, \mathrm{H} 5, \mathrm{H} 6, \mathrm{H} 7, \mathrm{H} 11, \mathrm{H} 12, \mathrm{H} 15$, and H16. The not supported hypotheses are H2, H4, H8, H9, H10, H13, and H14. The hypothesis is proven to show a significant effect if the Critical Ratio (C.R) value $>$ the table value of 1.96 or the $p$-value is < the alpha value of 0.05 . The magnitude of the influence can be seen from the size of the standardized estimate. If the 
standardized estimate value shows a positive value, it can be interpreted that each hypothesis has a positive influence.

Hypothesis one is in line with Senyo \& Osabutey (2020) study that supports the statement that behavioral intention has a positive effect on the actual use of ShopeePay's mobile payment service, which has a critical ratio value of 2.718 and a p-value of 0.007 , indicating that the hypothesis is supported. In line with the research of Peter \& Olson (2008), this proves that behavioral intention is the proportion that connects the user's desire to use ShopeePay's mobile payment with the user's actual use of it in the future. The higher the possibility or desire of the user to use ShopeePay mobile payment, the greater the user will use ShopeePay mobile payment to complete their transactions continuously. This argument is because the benefits of ShopeePay that are already known to the user will increase the user's desire to use ShopeePay, which ultimately makes the user use ShopeePay as a means of payment. Many consumers have a great desire to use ShopeePay. Based on the behavioral intention variable statements, users said they would use ShopeePay in transactions if they had adequate internet access. The existence of attractive discounts when using ShopeePay also increases their desire actually to use ShopeePay.

Hypothesis two is not supported, in line with Singh et al.'s (2020) research results. This result proves that perceived benefits felt by users when using ShopeePay mobile payment do not affect consumers to use ShopeePay. The benefits consumers feel in using ShopeePay's mobile payments for actual transactions do not encourage users to improve their performance. According to Singh et al. (2020), the positive attributes of fintech can affect the users' behavioral intentions towards this fintech but do not affect users using them for various technical reasons such as being comfortable with other fintech, reputation for other fintech. This argument is because respondents feel the benefits of ShopeePay are the same as the benefits of fintech they previously used.

Hypothesis three, namely, the relationship between perceived usefulness and behavioral intention, has a positive relationship as evidenced by the results of the standardized estimate of 0.102 with a critical ratio value C.R. of 2.514 and a pvalue of 0.012. These values indicate that hypothesis three is supported, following Singh et al.'s (2020) research results. This result proves that perceived benefits felt by users when using ShopeePay mobile payment affect users' desire to use ShopeePay mobile payment positively. In other words, the more benefits that ShopeePay will provide to users, the more users will want to use ShopeePay. This statement is because ShopeePay can support the performance of its users so that ShopeePay will be more attractive to use.

Hypothesis four shows that the relationship between perceived ease of use and actual use has no effect. Hypothesis four has a standardized estimate of 0.118 with a critical ratio value C.R. of 1.430 and a p-value of 0.153 , indicating that $\mathrm{H} 4$ is not supported, contrary to Singh et al.'s (2020) study results. This result proves that the ease of using ShopeePay mobile payment does not affect consumers' use ShopeePay mobile payment. The ease of using ShopeePay itself does not make users use ShopeePay as a means of payment. Just like the explanation in $\mathrm{H} 2$, there are other possibilities, such as convenience in other fintech, that make 
ShopeePay less attractive (Singh et al., 2020).

Hypothesis five is supported, in line with Singh et al.'s (2020) research results. This result proves that the ease of using ShopeePay's mobile payment positively affects consumers' desire to use it. In other words, the higher a person's belief in the ease of using ShopeePay as a means of payment, the greater the desire to use ShopeePay. The improvement and ease of a feature make people interested in using fintech because it is less complicated and easier to use.

Hypothesis six is supported, in line with Singh et al.'s (2020) research results. This result proves that the ease of using ShopeePay's mobile payment positively affects consumers' benefits when using it. In other words, the higher one's belief in the ease of using ShopeePay as a means of payment, the greater the belief in the benefits that users will get when using ShopeePay. According to Singh et al. (2020), no matter how large the benefits received from technology, it will be useless if the technology is challenging to use.

Hypothesis seven is supported, in line with Singh et al.'s (2020) research results. This result proves that social influence can positively influence consumers to use ShopeePay mobile payment as a means of payment. When someone has never experienced using technology, that person will consider the opinions and perceptions of others more in assessing a technology (Singh et al., 2020). This argument means that the more social influence to use ShopeePay, the more likely the users will use ShopeePay to complete their transactions on an ongoing basis.

Hypothesis eight is not supported, in line with Singh et al.'s (2020) research results. This result proves that the social influence does not affect consumers' desire to use ShopeePay mobile payment in the future. The influence of the social environment they get does not affect them to use ShopeePay as a means of payment. ShopeePay's mobile payment will always involve the user's financial value so that the decision to use a fintech technology will be more influenced by individual decisions and needs and not by external social influences (Senyo et al., 2020).

Hypothesis nine is not supported, in line with Singh et al.'s (2020) research results. This result proves that the social influence does not affect users' confidence in the perceived benefits when using ShopeePay mobile payment. The social impact that users receive for using ShopeePay as a means of payment does not help users improve their performance. This argument is because users' benefits in using ShopeePay will be more pronounced when they use it, so social encouragement alone does not affect users' belief in the benefits of ShopeePay.

Hypothesis ten is not supported, contrary to Singh et al.'s (2020) research results. The testing of this hypothesis shows the standardized estimate value of 0.039 with a critical ratio value C.R. of 0.981 and the p-value of 0.327 . This result proves that the social influence received by consumers does not affect the ease of using ShopeePay as a means of payment. Social influence can involve someone participating in the ecosystem of a technology (Albayati et al., 2020). However, the ease of using a technology depends on each user's ability to adapt to the technology, not on the social influences. In other words, everyone sometimes feels that technology is easy to use, but other people who use the 
same technology may find the technology difficult to use so that external factors do not influence the perceived ease of use variable.

Hypothesis eleven is supported, in line with Singh et al.'s (2020) research results. This result proves that the information provided by ShopeePay mobile payment positively affects the benefits that consumers feel when using it. It can be interpreted that the more accurate the information provided by ShopeePay, the higher the consumers' belief in the benefits of using ShopeePay as their means of payment. This argument is because the technology that provides clear information and its effectiveness will help users become aware of the benefits that ShopeePay will provide if they use it (Gefen, 2000).

Hypothesis twelve is supported, in line with Singh et al.'s (2020) research results. This result proves that the information provided by ShopeePay mobile payment positively affects the ease of using ShopeePay. In other words, the more accurate the information provided by ShopeePay, the easier it is for users to use ShopeePay in completing their transactions. When technology can provide clear and practical information in its processing time, users will not find it difficult to understand or use the technology.

Hypothesis Thirteen is not supported, in line with Singh et al.'s (2020) research results. This result proves that the information provided by ShopeePay's mobile payment does not affect the social influence of ShopeePay's mobile payment. The information provided does not affect the social influence of mobile payment because the understanding of information may differ according to each user's preferences. Users who feel that the ShopeePay application lacks service excellence or feels that ShopeePay is less superior to other fintech will be hesitant to invite others to use ShopeePay as a means of payment.

Hypothesis fourteen has a standardized estimate of 0.074 with a critical ratio value C.R. of -0.035 and a p-value of 0.972 . These values indicate that H14 is not supported, contrary to Singh et al.'s (2020) research results. This result proves that confidence in Security when making transactions with ShopeePay does not affect user confidence in the perceived benefits when using ShopeePay mobile payment. In other words, the security features that ShopeePay has only act as a support for the application, not as an addition to the benefits obtained when using this mobile payment. Even though technology has a good level of security for users, the technology will still not be used if it does not provide benefits for its users.

Hypothesis fifteen has a standardized estimate of 0.075 with a critical ratio value C.R. of 4.830 and a p-value of $<0.01(* * *)$. These values indicate that H15 is supported, in line with Singh et al.'s (2020) research results. This result proves that confidence in Security when making transactions with ShopeePay positively affects the ease of using ShopeePay as a means of payment. In other words, the higher the security features provided by ShopeePay's mobile payment, the higher the ease of use for users to transact with ShopeePay. Users certainly demand Security for their transactions due to the lack of face-to-face interaction and the high risk and uncertainty when conducting online transactions $(\mathrm{Gu}$, Lee, \& Suh, 2009; Pavlou, 2003). ShopeePay can provide information about security features in its application so that users feel more comfortable and safer in using it. The 
ease of using ShopeePay supported by good Security will further add to the users' convenience.

Hypothesis sixteen is supported, in line with Singh et al.'s (2020) research results. This result proves that confidence in Security when conducting transactions with ShopeePay positively affects social influence in using ShopeePay as a means of payment. When many users believe that ShopeePay has good security features for their online transactions, more people will give positive feedback to ShopeePay. In other words, the higher the Security features provided by ShopeePay's mobile payment, the greater the social influence for using ShopeePay.

\section{CONCLUSION}

Seven hypotheses show a positive influence; namely, behavioral intention felt by ShopeePay consumers has a positive influence on actual use; perceived usefulness has a positive effect on behavioral intention; perceived ease of use has a positive effect on behavioral intention and perceived usefulness; social influence has a positive effect on actual use; responsiveness has a positive effect on perceived usefulness and perceived ease of use; and security has a positive effect on perceived ease of use and social influence. The results of the study for the other nine hypotheses do not show a significant effect.

A recommendation for Shopee as an application that provides ShopeePay mobile payment services is to increase the number of merchants that use ShopeePay, both merchants in malls and other retailers. This refers to $\mathrm{H} 3$ results that show perceived usefulness has a positive effect on behavioral intention. By looking at the mean results in the statement, it can be said that easiness in making payments at merchants can influence someone to use ShopeePay.

\section{REFERENCES}

Albayati, H., Kim, S. K., \& Rho, J. J. (2020). Accepting financial transactions using blockchain technology and cryptocurrency: A customer perspective approach. Technology in Society, 62, 101320.

Annas, M., \& Anshori, M. A. (2021). Problematics of Determining Interest in Peer-to-peer Lending in Indonesia. Jurnal Media Hukum, 28(1), 102-117.

Castells, M. (2004). The network society A cross-cultural perspective. Edward Elgar.

Gai, K., Qiu, M., \& Sun, X. (2018). A survey on FinTech. Journal of Network and Computer Applications, 103, 262-273.

Gefen, D. (2000). E-commerce: the role of familiarity and trust. Omega, 28(6), $725-737$.

Grohmann, A. (2018). Financial literacy and financial behavior: Evidence from the emerging Asian middle class. Pacific-Basin Finance Journal, 48, 129143.

Gu, J.-C., Lee, S.-C., \& Suh, Y.-H. (2009). Determinants of behavioral intention to mobile banking. Expert Systems with Applications, 36(9), 11605-11616.

Hair, J. F. (2009). Multivariate data analysis (7th ed.). Upper Saddle River: Prentice Hall. 
Hsueh, S.-C., \& Kuo, C.-H. (2017). Effective matching for P2P lending by mining strong association rules. Proceedings of the 3rd International Conference on Industrial and Business Engineering, 30-33.

Isaac, O., Aldholay, A., Abdullah, Z., \& Ramayah, T. (2019). Online learning usage within Yemeni higher education: The role of compatibility and tasktechnology fit as mediating variables in the IS success model. Computers \& Education, 136, 113-129.

Pavlou, P. A. (2003). Consumer acceptance of electronic commerce: Integrating trust and risk with the technology acceptance model. International Journal of Electronic Commerce, 7(3), 101-134.

Peter, J. P., \& Olson, J. C. (2008). Consumer Behavior and Marketing Strategy, McGrawHill. Boston: McGraw Hill.

Purwianti, L., \& Tio, K. (2017). Faktor-faktor yang mempengaruhi behavioural intention. Jurnal Manajemen Maranatha, 17(1), 15-32.

Sastiono, P., \& Nuryakin, C. (2019). Inklusi keuangan melalui program layanan keuangan digital dan laku pandai. Jurnal Ekonomi Dan Pembangunan Indonesia, 19(2), 242-262.

Senyo, P. K., \& Osabutey, E. L. C. (2020). Unearthing antecedents to financial inclusion through FinTech innovations. Technovation, 98, 102155.

Singh, S., Sahni, M. M., \& Kovid, R. K. (2020). What drives FinTech adoption? A multi-method evaluation using an adapted technology acceptance model. Management Decision.

Suryono, R. R. (2019). Financial technology (fintech) dalam perspektif aksiologi. Masyarakat Telematika Dan Informasi Jurnal Penelitian Teknologi Informasi Dan Komunikasi, 10(1), 52.

Teo, A.-C., Tan, G. W.-H., Ooi, K.-B., \& Lin, B. (2015). Why consumers adopt mobile payment? A partial least squares structural equation modelling (PLSSEM) approach. International Journal of Mobile Communications, 13(5), 478-497.

Venkatesh, V., Thong, J. Y. L., \& Xu, X. (2012). Consumer acceptance and use of information technology: extending the unified theory of acceptance and use of technology. MIS Quarterly, 36(1), 157-178.

Zhou, T. (2013). An empirical examination of continuance intention of mobile payment services. Decision Support Systems, 54(2), 1085-1091. 